\title{
BANGMEJAR \\ Solusi Cerdas Mengembangkan Media Pembelajaran Anak Usia Dini
}

\author{
S. Ichas Hamid 1
}

\begin{abstract}
ABSTRAK
Berlimpahnya media permainan dan pembelajaran produk teknologi modern, ditenggarai bukan saja tidak aman bagi kesehatan, tetapi juga tidak selalu sesuai bagi kepentingan perkembangan (psikologis) dan kebutuhan belajar anak serta kultur filosofis bangsa. Hal itu tentu saja merupakan persoalan yang harus dihadapi segenap pendidik dan orang tua yang menyadari akan pentingnya memberikan pengalaman dan fasilitas belajar yang tepat, dalam arti sesuai dengan kebutuhan perkembangan anak usia dini. Sementara pengetahuan dan penyadaran terhadap jenis dan produk media permainan sebagai wahana pembelajaran tradisional yang ada sebagai warisan budaya lokal Jawa Barat umumnya, jikapun sudah mulai dirintis secara swadaya oleh kelompok masyarakat etnik Sunda, keberadaannya masih sangat terbatas dan belum secara khusus serta fokus terkait keperluan langsung institusi pendidikan. Bahwa keberadaan bengkel kerja sebagai laboratorium program studi merupakan tuntutan pengembangan yang secara programatik dan kelembagaan diharapkan memberi sumbangan positif sebagai wahana multiguna baik akademik, vokasional dan sosial bagi para mahasiswa sebagai calon sarjana pendidikan anak usia dini, maupun komunitas profesi / praktisi pendidikan anak, para orang tua dan khalayak luas pemerhati pendidikan anak umumnya. Untuk itu, kiprah ini diproyeksikan dapat memfasilitasi kelengkapan kegiatan pembelajaran segenap civitas akademika secara multi dimensi: teoritik dan praktik, konseptual dalam arti rekacipta-kreatif, sosial dan kultural dalam arti human interaktive melalui wahana kegiatan produktif dan berdaya-guna.

Kata Kunci: Bangmejar, Media Pembelajaran, Anak Usia Dini
\end{abstract}

\section{A. PENDAHULUAN}

Pengembangan Media Pembelajaran menjadi bagian yang tak terpisahkan dari kiprah pendidikan pada semua jenjang dan bidang pelajaran keilmuan, terlebih bagi kepentingan pendidikan anak usia dini yang nota-bene kebutuhan belajarnya tidak terpisahkan dari dunia bermain. Karena itu, pemberian dan penggunaan alat pembelajaran pada anak usia dini dapat dikatakan pula sebagai pemahaman terhadap kebutuhan bermain anak. Bermain itu sendiri, sejatinya merupakan fitrah kehidupan tidak saja anak-anak dan bahkan mahluk bernama manusia. Tetapi kepentingan 'bermain' bagi anak menjadi fase krusial dan kritikal di dalam kerangka mendorong proses tumbuh-kembangnya sebuah generasi memenuhi tuntutan kehidupan dan citra peradabannya. Bermain sebagai media belajar, dan belajar seraya bermain telah menjadi keniscayaan bagi penyelenggaraan Pendidikan Anak Usia Dini. Karena itu, seiring dengan perkembangan ikhtiar yang tiada henti dalam

${ }^{1}$ Dosen PGPAUD UPI Kampus Cibiru 
kerangka bermain dan pembelajaran bagi anak di tengah masyarakat terus dilahirkan baik secara konsepsional memenuhi hajat pendidikan maupun sekedar alat dan media penghiburan semata.

Jika sejarah kebudayaan dan pendidikan di dalamnya dipahami sebagai loncatan kehidupan, kemajuan dan produk yang menandai masa panjang sebelumnya dinisbahkan sebagai fase tradisional. Pada satu kurun transisi ketika mulai ditinggalkan oleh bergulirnya produk inovasi baru seiring modernisasi di berbagai bidang kehidupan. Memenuhi kebutuhan bermain baik sebagai media hiburan dan pendidikan di tengah masyarakat - termasuk di tanah air, dapat dibedakan setidaknya antara yang bersifat modern dan tradisional. Produk permainan modern ditandai dengan loncatan kemajuan hasil inovasi teknologi yang hampir tanpa henti, hingga berpotensi membawa dampak (negatif) yang tidak dikehendaki jika tidak disertai pembatasan oleh pihak yang bertanggungjawab. Sementara media dan permainan tradisional merupakan produk kriya dan kreatifitas sederhana yang merupakan hasil interelasi intens antara diri manusia dengan alam tempatnya menjalani keberadaan. Terlahirnya produk kriya dan kreatifitas sederhana hingga hasil inovasi teknologi canggih di tengah masyarakat kita dalam perspektif pendidikan menjadi hal yang sama penting dan karenanya saling melengkapi. Karena itu, menjadi kelebihan dari generasi yang dilahirkan sekarang adalah beragamnya sumber-sumber dan media pembelajaran yang diperlukan, tinggal memilih dan memilahnya.

Bahwa di tengah membanjirnya produk-produk permainan anak baik yang bersifat educated maupun sekedar entertainly yang dihasilkan industri manufactur maupun home industri; yang terbuat dari bahan-bahan alamiah hingga hasil olah teknologi tinggi, dalam dekade ini tengah tumbuh kesadaran masyarakat pendidikan khususnya untuk back to basic, kembali mencari nilai-nilai yang terdapat pada keseimbangan alam, pada keramahan sinergi kehidupan dan bukan kemarahan kekuatan yang menakutkan. Bahwa pemanfaatan produk dan semi proses teknologi maju di jaman kini tentu penting karena bagian dari realitas kemajuan kehidupan itu sendiri. Tetapi tidak melupakan kekayaan alam dan budaya tradisional lokal dalam dan dengan kesederhanaanya pun menjadi suatu langkah cerdas dalam kerangka memberikan pendidikan yang lengkap bagi generasi muda kita. Selebihnya urgensi pengembangan media pembelajaran APE anak usia dini khususnya di dasarkan pada temuan bahwa "diantara media pembelajaran yang banyak dijual bebas di tengah masyarakat dalam berbagai bentuk, rupa, dsb., tidak sedikit yang potensial bermasalah, karena dibuat lebih sekedar menarik minat anak semata, tidak merupakan hasil kajian komprehensif dari berbagai sudut kepentingan anak, mulai dari keamanan bahan yang dipergunakan maupun efek psikologis bagi perkembangan anak usia dini khususnya". (Ichas Hamid dkk, 2013) Untuk itu, keberadaan Bangmejar di lingkungan Program Studi PGPAUD UPI Kampus Cibiru, baik sebagai bengkel kerja dan proyek lanjutnya menjadi pusat kajian diharapkan mampu memberikan sumbangan setidaknya antara lain sebagai :

1) Sarana pembelajaran bagi segenap sivitas akademika internal UPI dan praktisi PAUD di tengah masyarakat luas akan kepentingan pengembangan APE 
2) Wahana pengembangan prototype APE baru baik modern maupun tradisional

3) Pusat pengkajian dan pengujian standar mutu produk berkenaan dengan kegunaan, keamanan dan keselamatan bagi kepentingan kesehatan dan pendidikan anak.

\section{B. SAMPEL PRODUKSI PENGEMBANGAN}

1. Sample Produk Pengembangan Prototype baru :

\begin{tabular}{|l|l|l|l|}
\hline No & \multicolumn{1}{|c|}{ Nama Produk } & Produk Kreatif & Jenis \\
\hline 1 & Suung Ngentrung; & Uus Kusnadi Dkk. & Mainan bunyi-bunyian \\
\hline
\end{tabular}

\section{Keterangan :}

Disebut Suung Ngentrung, karena bentuknya menyerupai Cendawan / sejenis jamur yang biasa tumbuh dimusim hujan, dalam bahasa Sunda disebut Suung. Dibuat sedemikian rupa menggunakan bahan dasar kayu, jika dipukul berbunyi ngentrung. Diproyeksikan produk ini memenuhi fungsi sebagai alat pengenalan bunyi-bunyian di dalam pembelajaran musik bagi anak, selain pengenalan benda alam buatan, yakni Cendawan yang sering tumbuh di sekitar halaman rumah / sekolah.

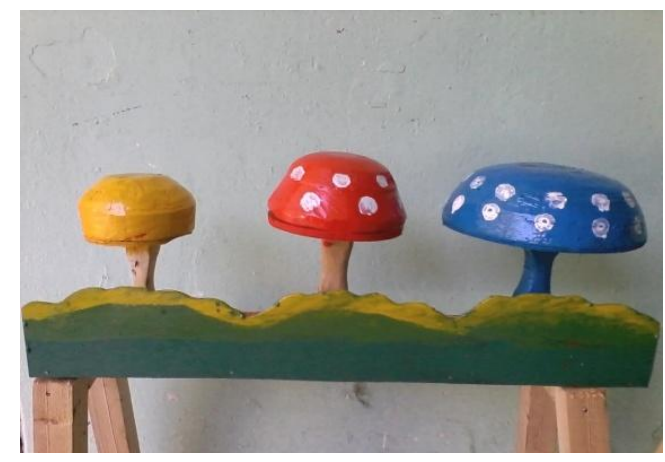

2. Sample Produk Pengembangan Inovasi :

\begin{tabular}{|c|l|l|l|}
\hline \multicolumn{2}{|c|}{ Ujicoba Produk Pengembangan1/2013 } \\
\hline No & \multicolumn{1}{|c|}{ Nama } & \multicolumn{1}{c|}{ Deskripsi } & \multicolumn{1}{c|}{ Hasil Inovasi } \\
\hline 1 & Bakiak Ceria & $\begin{array}{l}\text { Bentuk asal : terbuat dari kayu } \\
\text { dengan tali karet ban bekas, } \\
\text { Produk : spontan masyarakat } \\
\text { tidak terdapat di pasar / }\end{array}$ & $\begin{array}{l}\text { Pengembangan bentuk } \\
\text { menyerupai Ikan, dilapisi } \\
\text { pengaman dari bahan karet } \\
\text { sintetis }\end{array}$ \\
\hline 2 & $\begin{array}{l}\text { Egrang } \\
\text { Batok Kelapa }\end{array}$ & $\begin{array}{l}\text { Bentuk asal : terbuat dari tempurung } \\
\text { kelapa } \\
\text { Produk : spontan masyarakat } \\
\text { Tidak terdapat di pasar }\end{array}$ & $\begin{array}{l}\text { Penambahan bahan } \\
\text { pengaman pada alas dan } \\
\text { tali }\end{array}$ \\
\hline 3 & $\begin{array}{l}\text { Kuda } \\
\text { Lumping }\end{array}$ & $\begin{array}{l}\text { Terbuat dari bilik bambu / gedeg, } \\
\text { dijual di pasar kriya }\end{array}$ & $\begin{array}{l}\text { Dibuat ulang menggunakan } \\
\text { berbagai bahan yang } \\
\text { mudah di dapat ; karton, } \\
\text { daun kelapa, dll }\end{array}$ \\
\hline
\end{tabular}



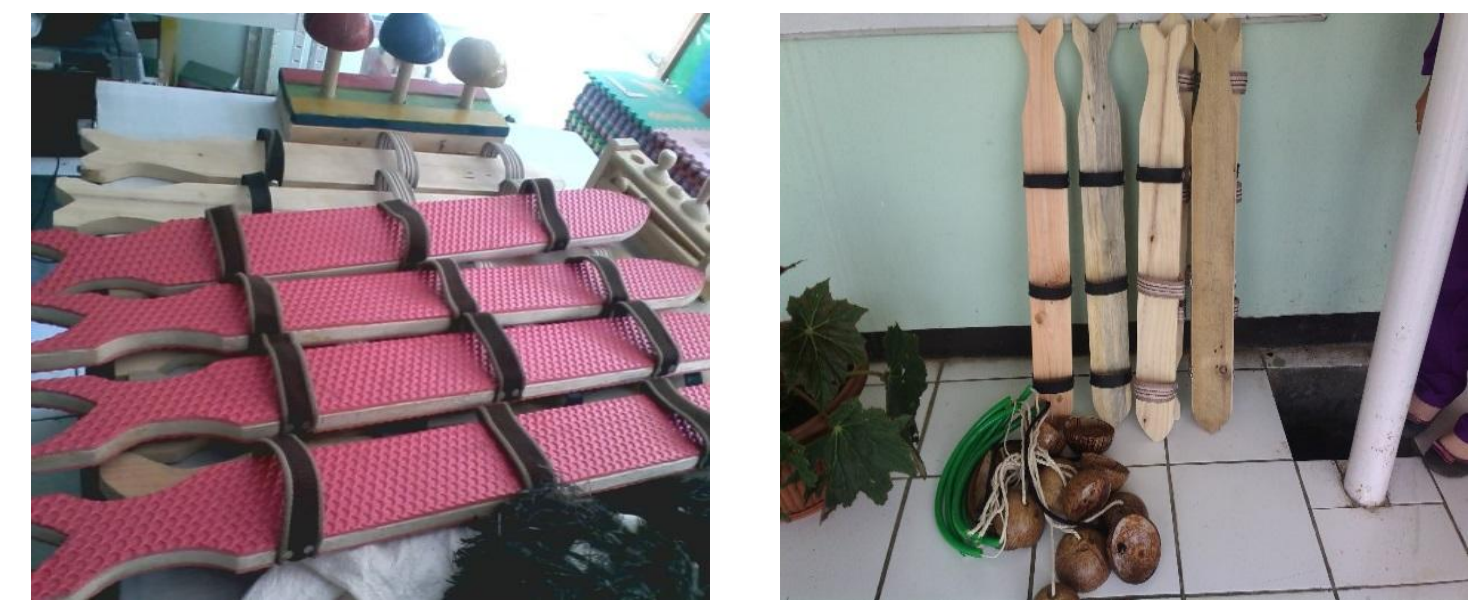

\begin{tabular}{|c|c|c|c|}
\hline \multicolumn{4}{|c|}{ Konseptualisasi / Proyeksi Ujicoba 2/ 2014} \\
\hline No & Nama & Deskripsi & Hasil Inovasi \\
\hline 1 & $\begin{array}{l}\text { Topeng } \\
\text { Karakter } \\
\text { - Suasana } \\
\text { hati } \\
\text { - Tokoh fabel }\end{array}$ & $\begin{array}{l}\text { Bentuk awal : terbuat dari } \\
\text { berbagai bahan seperti kayu, } \\
\text { karet, plastik Produk: Home } \\
\text { Industri, dijual di pasar } \\
\text { kerajinan rakyat }\end{array}$ & $\begin{array}{l}\text { Dapat dibuat dari bahan yang } \\
\text { mudah didapat menggunakan } \\
\text { karton, bubur kertas. Untuk } \\
\text { mengungkap ragam karakter } \\
\text { tokoh dimainkan dalam ujud } \\
\text { gerak dan lagu adopsi dari cerita } \\
\text { anak ke dalam skenario yang } \\
\text { dibuat guru }\end{array}$ \\
\hline 2 & $\begin{array}{l}\text { Bangku } \\
\text { Goyang }\end{array}$ & $\begin{array}{l}\text { Bentuk awal : terbuat dari } \\
\text { papan kayu, bentuk } \\
\text { sederhana, } \\
\text { Produk : internal } \\
\text { tidak terdapat di pasar }\end{array}$ & $\begin{array}{l}\text { Pengggunaan bahan kayu cukup } \\
\text { aman, dengan modifikasi bentuk } \\
\text { benda fungsional (perahu) atau } \\
\text { satwa (Ikan) }\end{array}$ \\
\hline 3 & $\begin{array}{l}\text { Papan } \\
\text { Congklak }\end{array}$ & $\begin{array}{l}\text { Bentuk awal : terbuat dari } \\
\text { bahan kayu, dengan ukuran } \\
\text { standar peruntukan anak } \\
\text { sudah besar, } \\
\text { Produk : home industry dijual } \\
\text { di pasar umum }\end{array}$ & $\begin{array}{l}\text { Dibuat dari bahan kayu dengan } \\
\text { modifikasi khusus jumlah lubang } \\
\text { dan bentuk aneka binatang }\end{array}$ \\
\hline 4 & $\begin{array}{l}\text { Bola Pelepah } \\
\text { Pisang }\end{array}$ & $\begin{array}{l}\text { dibuat dari pelepah pisang } \\
\text { kering, digulung menjadi bola, } \\
\text { tidak terdapat di pasar }\end{array}$ & $\begin{array}{l}\text { dibuat dari pelepah pisang } \\
\text { kering, digulung menjadi bola }\end{array}$ \\
\hline
\end{tabular}

\section{KESIMPULAN}

Sebagaimana prasarana workshop umumnya, keberadaan bengkel kerja program studi, selain dipastikan akan mengantarkan lulusannya sebagai sarjana yang memenuhi standar keilmuan dalam bidang PAUD, juga membuka peluang strategis bagi mahasiswa dalam memperoleh pengalaman dan bekal keterampilan penunjang yang secara faktual terkait dengan tuntutan vokasional sebagai praktisi PAUD. Selain kegunaan langsung bagi para mahasiswa PGPAUD khususnya, khalayak luas umumnya, secara kelembagaan bagi Program Studi PGPAUD itu 
sendiri keberadaan bengkel kerja Pengembangan Media Pembelajaran APE PAUD direkomendasikan berfungsi sebagai : 1) Pusat penelitian dan pengembangan media pembelajaran terutama yang berbasis budaya lokal; 2) Meningkatkan kualitas perkuliahan dengan penambahan praktikum yang berkenaan dengan beberapa mata kuliah; 3) Meningkatkan life skills mahasiswa sebagai bekal berwirausaha di masa depan; 4) Sentral inovasi model dan pembuatan media pembelajaran anak usia dini berbasis budaya lokal. Hasil sementara analisis produksi dan ujicoba sejumlah pilihan media Alat Permainan Edukatif PAUD yang berbasis budaya local khususnya, seperti yang terlihat di tengah masyarakat / pasar mainan anak, umumnya tidak dilengkapi deskripsi kelayakgunaan, petunjuk teknis dan penjelasan keamanan pakai bagi anak. Untuk itu keberadaan bengkel kerja Bangmejar diharapkan mampu melengkapi kekurangan alat mainan anak produk masyarakat dan pabrikan selain mengembangkan prototype produk inovasi sendiri.

\section{DAFTARPUSTAKA}

Ichas Hamid, Solihin, dkk., 2013, Pengembangan Bengkel Kerja Media Pembelajaran Pendidikan Anak Usia Dini Berbasis Budaya Lokal, PGPAUD UPI Kampus Cibiru (Laporan Proyek Pengembangan Keunggulan Institusi). 